\title{
Suppression of Anti-DNA Antibody Synthesis In Vitro by a Cross-reactive Antiidiotypic Antibody
}

\author{
Alan Epstein, Mark Greenberg, Betty Diamond, and Arthur I. Grayzel \\ Department of Medicine, Division of Rheumatology, Department of Microbiology and Immunology and Irvington House \\ Institute for Medical Research, Montefiore Medical Center/Albert Einstein College of Medicine, Bronx, New York 10467
}

\begin{abstract}
An understanding of the regulatory mechanisms that govern the humoral immune response will be facilitated by the availability of techniques for the measurement of specific antibody production in vitro. We have developed an enzyme-linked immunosorbent assay system for the measurement of in vitro anti-DNA antibody production by peripheral blood mononuclear cells (PBMC) from patients with systemic lupus erythematosus. Using this technique, the PBMC from 74\% of serologically active SLE patients produced levels of anti-DNA antibodies that were $>2$ SD above the mean of $18 \pm 9 \mathrm{IU} / \mathrm{ml}$ for normal subjects. Furthermore, the addition of 3I, a monoclonal anti-idiotypic antibody that recognizes a cross-reactive determinant on anti-DNA antibodies, was shown to specifically inhibit anti-DNA production in vitro.
\end{abstract}

\section{Introduction}

The concept that interactions between idiotype and antiidiotype play a role in the regulation of the immune response was initially proposed by Jerne (1). Since his original hypothesis was put forward antiidiotypes have been shown in many experimental animal systems to regulate the expression of idiotypic antibodies. Studies on human cells likewise have shown that antiidiotype can inhibit the in vitro production of idiotypic antibodies $(2,3)$.

To investigate what regulatory mechanisms might govern the humoral immune response in patients with systemic lupus erythematosus (SLE) it is necessary to be able to measure the synthesis of specific autoantibodies. We have adapted an enzymelinked immunosorbent assay (ELISA) system originally developed to measure anti-DNA antibodies in serum for the measurement of anti-DNA antibodies spontaneously produced by. cultured peripheral blood mononuclear cells (PBMC) ${ }^{1}$ obtained from patients with SLE. Using a cross-reactive mouse monoclonal antiidiotype to human anti-DNA antibodies (4) we have

Address reprint requests to Dr. Grayzel, Montefiore Medical Center, 111 East 210 St., Bronx, NY 10467.

Received for publication 25 September 1986.

1. Abbreviations used in this paper: ds-DNA, double-stranded DNA; PBMC, peripheral blood mononuclear cells; PNPP, $p$-nitrophenyl phosphate.

J. Clin. Invest.

(c) The American Society for Clinical Investigation, Inc.

0021-9738/87/03/0997/04 \$1.00

Volume 79, March 1987, 997-1000 examined the effect of the antiidiotype on the synthesis of antiDNA antibodies in vitro.

\section{Methods}

Patients. All patients with SLE met at least four American Rheumatism Association criteria for the diagnosis of SLE (5). All but one patient had serologically active SLE, and most had clinically active disease as well. The majority of these patients were receiving prednisone at the time of study, and several were receiving azathioprine in addition. The control group were healthy subjects without evidence of SLE or other rheumatic disorder and were not taking any drug known to induce a positive antinuclear antibodies.

Assay for serum anti-DNA antibodies. Serum anti-double-stranded DNA (ds-DNA) antibodies were measured by an ELISA system marketed as Cordia-N by Cordis Laboratories, Miami, FL. Plastic disks containing isothiocynate groups coupled to ds-DNA by incubation in $0.1 \mathrm{M}$ carbonate buffer at $\mathrm{pH} 9.6$ followed by extensive washing were incubated with $5 \mu \mathrm{l}$ of test serum diluted in $0.5 \mathrm{ml}$ of $0.01 \mathrm{M}$ phosphate-buffered saline, $\mathrm{pH} 7.4$, containing $6 \%$ bovine serum albumin and $0.05 \%$ Tween 20 (ICI United States, Inc., Wilmington, DE) for $45 \mathrm{~min}$ at $37^{\circ} \mathrm{C}$ with shaking. Each disk was then washed five times with $0.002 \mathrm{M}$ Tris-saline, pH 7.8. A mixture of antigen-purified, alkaline phosphatase-labeled goat anti-human IgG and IgM antibodies was added for $45 \mathrm{~min}$ at $37^{\circ} \mathrm{C}$. The disks were again washed five times, transferred to clean, unused vials, and incubated with $1.0 \mathrm{ml}$ of the $p$-nitrophenyl phosphate (PNPP) substrate for $20 \mathrm{~min}$ at $37^{\circ} \mathrm{C}$. The reaction was terminated by the addition of $0.1 \mathrm{ml}$ of $3 \mathrm{~N} \mathrm{NaOH}$ and the absorbance at $405 \mathrm{~nm}$ was measured against a distilled water blank. The characteristics of this assay system have been described (6).

Assay for in vitro anti-DNA production. $40 \mathrm{ml}$ of blood were obtained from normal subjects and from patients with SLE. PBMC were isolated by standard methods of centrifugation over Ficoll-Hypaque, followed by several washes with HB-101 medium (Hana Media, Berkley, CA), a serum-free lymphocyte growth medium containing $1 \mathrm{mg} / \mathrm{ml}$ of protein. The PBMC were incubated in HB-101 for $4 \mathrm{~h}$ to remove any adsorbed immunoglobulin, then centrifuged, resuspended in HB-101, and incubated at a concentration of $2.5 \times 10^{6} \mathrm{PBMC} / \mathrm{ml}$ for $60 \mathrm{~h}$ on plastic disks containing covalently bonded ds-DNA (Cordis Laboratories) in an atmosphere of $6 \% \mathrm{CO}_{2}$ at $37^{\circ} \mathrm{C}$.

After incubation, anti-DNA antibody bound to the disks was measured in the same ELISA system described above for measuring antiDNA antibodies. Briefly, the PBMC were washed off the disks using a washing device that insures vigorous washing with Tris-buffered saline followed by vacuum aspiration. The disks were then incubated for $\mathbf{4 5}$ min at $37^{\circ} \mathrm{C}$ with a goat antiserum to human IgG and IgM conjugated with calf alkaline phosphatase (Cordis Laboratories). After six washes the disks were incubated for $45 \mathrm{~min}$ at $37^{\circ} \mathrm{C}$ with PNPP (Cordis Laboratories). The enzyme activity was terminated by the addition of sodium hydroxide and the absorbance was measured at $405 \mathrm{~nm}$. For each assay a standard curve was constructed using serial dilutions of a positive control serum, and the absorbance was converted to international units per milliliter. 
To determine the amount of 3I-reactive anti-DNA antibody synthesized in vitro, PBMC were incubated as described on disks coated with ds-DNA. The disks were incubated with the $3 I$ antiidiotype or with an isotype matched murine myeloma protein, followed by an affinitypurified alkaline phosphatase-linked goat anti-mouse IgG H+L +IgM (human serum absorbed) antiserum (Kirkegaard \& Perry Laboratories, Gaithersburg, MD) and PNPP.

Assay for the 3I idiotype in human sera. Sera were diluted 1:1,000 in $\mathrm{Pi} / \mathrm{NaCl}$ and absorbed to polystyrene wells. 3I culture supernatant or a dilution of $3 \mathrm{I}$ ascites was added. After incubation, the plates were washed and incubated with (35 S) methionine-labeled rat anti-mouse kappa light chain. The plates were again washed and assayed for radioactivity.

$3 I$ suppression studies. A mouse monoclonal antiidiotype (3I) that was cross-reactive with anti-DNA antibodies from a majority of patients with SLE was used in these studies. This antiidiotype is not anti-binding site. Its characteristics have been previously reported (4). The $3 \mathrm{I} \mathrm{IgG} \mathrm{was}$ purified from the ascitic fluid of BALB/c mice by ammonium sulfate precipitation followed by ion exchange chromatography on a DE-52 column. 3I at 14 or $28 \mu \mathrm{g} / \mathrm{ml}$ was added to PBMC that were incubated for $60 \mathrm{~h}$ in $1 \mathrm{ml}$ of HB-101. Anti-DNA activity was detected with an affinity-purified, phosphatase-labeled goat anti-human IgG, A, M (mouse serum absorbed) antiserum (Kirkegaard \& Perry Laboratories) and PNPP. The irrelevant monoclonal antibodies MOPC21 $(\gamma 1)$, AR13 ( $\gamma 1)$, and MPC11 $(\gamma 2 b)$ isolated from the ascitic fluid of BALB/c mice were used as controls. For each experiment disks to which mouse monoclonal antibody was added but no lymphocytes were used as blanks. In some experiments 3I was added to the PBMC at the end of the incubation just before the assay to determine if 31 demonstrated any interference with the ELISA system.

$F\left(a b^{\prime}\right)_{2}$ suppression studies. $F\left(a b^{\prime}\right)_{2}$ fragments of 3 I were produced by pepsin digestion for $24 \mathrm{~h}$ at $37^{\circ} \mathrm{C}$ and then isolated by Sephadex G100 gel chromatography. These were added to PBMC at concentrations varying from 5-20 $\mu \mathrm{g} / \mathrm{ml}$. A control containing the $\mathrm{F}\left(\mathrm{ab}^{\prime}\right)_{2}$ but no lymphocytes was included.

Assay for in vitro production of $\operatorname{IgG}$. PBMC obtained from patients with active SLE were preincubated for $4 \mathrm{~h}$ at $37^{\circ} \mathrm{C}$ in $\mathrm{HB}-101$ medium without supplementation. The cells $2 \times 10^{6} / \mathrm{ml}$ were centrifuged, resuspended in the same medium with and without the 3I antiidiotype at a concentration of $28 \mu \mathrm{g} / \mathrm{ml}$, and added to glass fiber disks covalently bonded to goat anti-human IgG. The cells were incubated for $3 \mathrm{~d}$, then removed from the disks by vigorous washing, and the disks developed in an ELISA assay using goat anti-human IgG, A, M (mouse serum absorbed) conjugated with alkaline phosphatase (Kirkegaard \& Perry Laboratories) and PNPP.

\section{Results}

Anti-DNA production in vitro. 23 patients with SLE were studied, 21 of them women and 2 men. All but one of the patients had serologically active disease. The mean serum anti-DNA for seven control subjects was $286 \pm 81 \mathrm{IU} / \mathrm{ml}$. 22 of 23 SLE patients had a serum titer of anti-DNA activity $>2$ SD above the mean of the controls.

As shown in Fig. 1, when $2.5 \times 10^{6} \mathrm{PBMC} / \mathrm{ml}$ from the patients with SLE were cultured in vitro for $60 \mathrm{~h}$ the mean antiDNA activity produced was $96.6 \pm 89.7 \mathrm{IU} / \mathrm{ml}$, as compared with $18 \pm 9 \mathrm{IU} / \mathrm{ml}$ for PBMC from the control subjects $(P<0.001)$. 17 of the 23 patients (74\%) produced levels of anti-DNA antibodies in vitro that were $>2$ SD above the mean for normal subjects. A number of factors were found to influence these results. Media containing serum reduced the measurable antiDNA antibodies, perhaps due in part to the presence of DNAase in the serum. The amount of anti-DNA produced was dependent on the duration of incubation and the number of PBMC added.

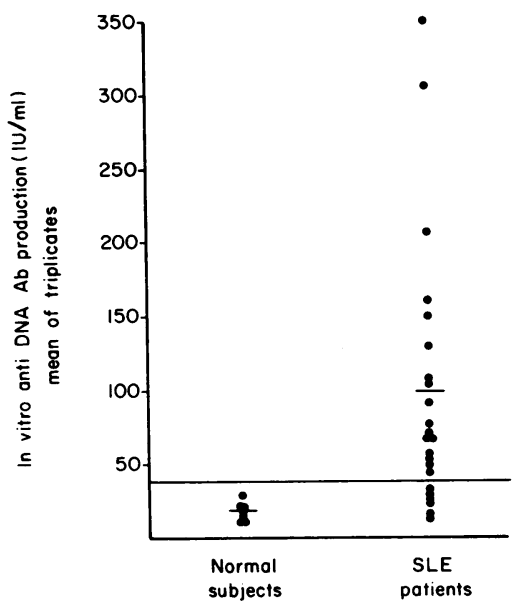

Figure 1. Production of anti-DNA antibodies (Ab) in vitro by PBMC from normal subjects and patients with SLE. Each point represents the mean of triplicate incubations. The mean of each group is indicated by a short horizontal line and 2 SD above the normal mean by the long horizontal line.

For example, in one experiment $5 \times 10^{5} \mathrm{PBMC}$ produced $60 \pm 5.8$ IU (SE) while $1 \times 10^{6} \mathrm{PBMC}$ produced $119 \pm 4.1 \mathrm{IU}$ and $2 \times 10^{6}$ PBMC produced $223 \pm 7.2$ IU, respectively. The length of incubation was limited to $72 \mathrm{~h}$ due to the fact that the ELISA disks could not be sterilized. When the media and disks were cultured for the presence of contamination, however, it was shown that they remained sterile up to $72 \mathrm{~h}$.

The anti-DNA activity detected reflects de novo synthesis. The addition of cycloheximide $(100 \mu \mathrm{g} / \mathrm{ml})$ to the culture system reduced the in vitro antibody response by $>85 \%$ (mean of four experiments). Furthermore, 24-h preincubation of PBMC in medium alone did not alter their anti-DNA activity (297 IU after $4 \mathrm{~h}$ vs. $329 \mathrm{IU}$ after $24 \mathrm{~h}$ of preincubation), demonstrating that de novo synthesis was being measured and not simply release of preformed anti-DNA antibodies.

Finally, as shown in Table I, a proportion of the anti-DNA antibody secreted by SLE PBMC in vitro bears the $3 I$ idiotype. The 3I antiidiotype binds to the anti-DNA antibodies produced in vitro. Monoclonal murine antibodies of the same isotype as

Table I. Detection of Idiotype on Anti-DNA Antibodies Synthesized by PBMC from a Patient with SLE

\begin{tabular}{lllcrr}
\hline Incubation & $\begin{array}{l}\text { 1st } \\
\text { antiserum }\end{array}$ & $\begin{array}{l}\text { 2nd } \\
\text { antiserum }\end{array}$ & $\begin{array}{l}\text { Mean } \\
\text { absorbance }\end{array}$ & SE & IU \\
\hline Medium alone & None & Anti-human & 215 & \pm 7 & \\
Medium alone & 3I, 1:5 & Anti-mouse & 157 & \pm 7 & \\
PBMC & None & Anti-human & 795 & \pm 23 & 108 \\
PBMC & 3I, 1:5 & Anti-mouse & 1,100 & \pm 131 & \\
PBMC & 31, 1:10 & Anti-mouse & 825 & \pm 18 & \\
& & & & &
\end{tabular}

Disks were incubated in triplicate with and without $2.5 \times 10^{6}$ PBMC in $1 \mathrm{ml}$ of HP-101 medium for $60 \mathrm{~h}$. After washing to remove the PBMC, some disks were first incubated as indicated with mouse antiidiotype (3I) for $45 \mathrm{~min}$ and washed. The disks were then incubated as indicated for $\mathbf{4 5}$ min with either a goat anti-human IgG,A,M (mouse serum absorbed) antibody or a goat anti-mouse IgG,M H+L (human serum absorbed) antibody both affinity purified and alkaline phosphatase labeled. After the addition of PNPP for $\mathbf{4 5}$ min absorbance at $\mathbf{4 0 5}$ $\mathrm{nm}$ was measured. In other experiments using the irrelevant monoclonal MOPC as the first antiserum the mean absorbance did not increase above that of medium alone. IU, international units. 
3I do not bind, showing a specific interaction of $3 \mathrm{I}$ with the antiDNA antibodies rather than rheumatoid factor activity in the culture supernatant.

Suppression of antibody synthesis by antiidiotypic antibody. 13 SLE patients were studied to determine if production of antiDNA antibodies could be suppressed by the 3I antiidiotype (Table II). All 13 patients had detectable anti-DNA antibodies in their serum and all had a baseline anti-DNA synthesis in vitro of $>40$ IU. 12 patients had 3I-reactive anti-DNA antibodies. The addition of $3 \mathrm{I}$ at concentrations of 14 or $28 \mu \mathrm{g} / \mathrm{ml}$ resulted in suppression of $>20 \%$ of anti-DNA synthesis by PBMC from 11 of 13 patients with SLE. The anti-DNA antibodies in the serum of these 11 patients demonstrated 3I reactivity, although there was not a linear correlation between the amount of 3 I reactivity in serum and the degree of suppression by the $3 I$ antiidiotype. Of the two patients whose antibody production was not suppressed by 3I, one did not demonstrate elevated 3I reactivity in serum.

To determine whether the 3I antiidiotype caused a nonspecific suppression of IgG production or a specific suppression of anti-DNA antibodies, PBMC from five SLE patients were as-

Table II. Effect of Antiidiotypic Antibody (3I) on the Synthesis of Anti-DNA Antibodies by PBMC from Patients with SLE

\begin{tabular}{|c|c|c|c|c|c|c|}
\hline \multirow[b]{4}{*}{ Pt. } & \multirow[b]{4}{*}{$\begin{array}{l}\text { Serum* } \\
\text { anti- } \\
\text { DNA }\end{array}$} & \multicolumn{5}{|c|}{ In vitro anti-DNA production } \\
\hline & & \multirow[b]{3}{*}{ Control } & \multicolumn{2}{|c|}{ 3I added } & \multicolumn{2}{|c|}{ MOPC added } \\
\hline & & & $\mathbf{I U}^{*}$ & $\begin{array}{l}\text { \% Sup- } \\
\text { pression }\end{array}$ & IU & $\begin{array}{l}\text { \% Sup- } \\
\text { pression" }\end{array}$ \\
\hline & & & \multicolumn{2}{|c|}{$\begin{array}{l}31 \text { added at } 28 \\
\mu \mathrm{g} / \mathrm{ml}\end{array}$} & \multicolumn{2}{|c|}{$\begin{array}{l}\text { MOPC added at } 28 \\
\mu \mathrm{g} / \mathrm{ml}\end{array}$} \\
\hline & $I U / m l$ & $I U^{*}$ & & & & \\
\hline C.J. & 954 & 106 & 60 & 43 & & \\
\hline R.S. & 600 & 71 & 53 & 26 & & \\
\hline J.M. & 2,140 & 49 & 32 & 35 & & \\
\hline V.B. & 1,241 & 309 & 173 & 44 & & \\
\hline A.O. & 1,010 & 147 & 74 & 50 & 107 & 27 \\
\hline \multirow[t]{2}{*}{ E.D. } & 1,055 & 49 & 33 & 32 & 45 & 8 \\
\hline & & & \multicolumn{2}{|c|}{$\begin{array}{l}\text { 3I added at } 14 \\
\mu \mathrm{g} / \mathrm{ml}\end{array}$} & \multicolumn{2}{|c|}{$\begin{array}{l}\text { MOPC added at } 28 \\
\mu \mathrm{g} / \mathrm{ml}\end{array}$} \\
\hline L.C. & 1,995 & 45 & 18 & 59 & & \\
\hline S.N. & 736 & 162 & 99 & 39 & 164 & +1 \\
\hline K.M. & 759 & 110 & 34 & 69 & & \\
\hline A. $R$. & 867 & 198 & 98 & 51 & 156 & 21 \\
\hline R.B. & 1,423 & 66 & 14 & 79 & 66 & 0 \\
\hline M.D. & 1,793 & 48 & 48 & 0 & 47 & 2 \\
\hline F.K." & 1,050 & 55 & 51 & 7 & & \\
\hline $\begin{array}{l}\text { Normal } \\
\text { values }\end{array}$ & $<450$ & $<40$ & & & & \\
\hline
\end{tabular}

IU, international units.

* Values from serum obtained at the same time as the PBMC used in the in vitro study.

* Values represent the mean of triplicate incubations.

${ }^{8}$ Mean percent suppression by all irrelevant mouse monoclonal antibodies at $28 \mu \mathrm{g} / \mathrm{ml}$ was $14.1 \pm 5.1 \mathrm{SE}, n=10$.

"Serum anti-DNA was 31 negative. sayed for in vitro production of IgG in the presence and absence of the $3 \mathrm{I}$ antiidiotype. In all five patients tested, 3I induced no decrease in secreted IgG. Cells from three of these five patients were simultaneously tested for secretion of anti-DNA antibodies; anti-DNA antibodies decreased by $20-56 \%$.

To determine whether the suppression noted above was the result of a macrophage-mediated antibody-dependent cytotoxicity we used $F\left(a b^{\prime}\right)_{2}$ fragments of $3 I$ in the test system at concentrations of $5-20 \mu \mathrm{g} / \mathrm{ml}$. There was no significant difference between the amount of suppression with the intact immunoglobulin and the $F\left(a b^{\prime}\right)_{2}$ fragment. Table III illustrates one experiment comparing suppression by $3 I$, the $F\left(a^{\prime}\right)_{2}$ fragment of $3 \mathrm{I}$ and three irrelevant mouse monoclonal antibodies. As can be seen, both intact $3 I$ and the $F\left(a b^{\prime}\right)_{2}$ fragment suppressed antiDNA antibody production, while the irrelevant monoclonal antibodies produced $<20 \%$ inhibition.

\section{Discussion}

Our results confirm earlier observations that PBMC from patients with SLE will spontaneously produce anti-DNA antibodies in vitro (7). The anti-DNA antibodies produced in vitro bear an idiotype found on the anti-DNA antibodies present in serum. Using a short-term culture system we have also shown that the addition of a mouse monoclonal antiidiotype can specifically suppress the in vitro synthesis of anti-DNA antibodies by PBMC from patients with SLE. This finding supports previous work that implicates antiidiotypes among the regulatory mechanisms that can control synthesis of anti-DNA antibodies in patients with SLE and previous studies reporting the inhibition of idiotypic antibodies by the addition of antiidiotype to in vitro cultures of human PBMC.

Abdou et al. (8) reported that the binding of human antiDNA antibodies to DNA could be blocked by autologous sera obtained from patients with SLE when their disease was in remission and by the $F\left(a^{\prime}\right)_{2}$ and Fab fragments derived from these sera. The inhibition of binding was interpreted as being due to the presence of antiidiotypes in the inactive sera that reacted

Table III. Effect of a Series of Mouse Monoclonal Antibodies on Anti-DNA Antibody Synthesis

\begin{tabular}{|c|c|c|c|}
\hline Patient & Additions & $\begin{array}{l}\text { Anti-DNA } \\
\text { antibody produced }\end{array}$ & Suppression \\
\hline & & $I U$ & $\%$ \\
\hline \multirow[t]{6}{*}{ R.B. } & None & 66 & - \\
\hline & $3 \mathrm{I}(14 \mu \mathrm{g})$ & 14 & 79 \\
\hline & 3I $F\left(a^{\prime}\right)_{2}(10 \mu g)$ & 28 & 56 \\
\hline & MOPC $^{21}(28 \mu \mathrm{g})$ & 64 & 3 \\
\hline & $\mathrm{AR}^{13}(28 \mu \mathrm{g})$ & 73 & +10 \\
\hline & $\mathrm{MPC}^{\prime \prime}(28 \mu \mathrm{g})$ & 52 & 21 \\
\hline \multirow[t]{4}{*}{ A.R. } & None & 198 & - \\
\hline & $3 \mathrm{I}(14 \mu \mathrm{g})$ & 98 & 51 \\
\hline & $\mathrm{MOPC}^{21}(28 \mu \mathrm{g})$ & 156 & 21 \\
\hline & $\mathrm{MPC}^{11}(28 \mu \mathrm{g})$ & 224 & +12 \\
\hline
\end{tabular}

Each value represents the mean of triplicate incubations of $2.5 \times 10^{6}$ PBMC in $1 \mathrm{ml}$ of HP-101 medium for $60 \mathrm{~h}$ with the additions indicated minus a blank incubated without PBMC. The range of blanks was from 12 to 15 international units (IU). 
with the binding site of the anti-DNA antibodies present in the sera of patients when their disease was active. Hahn and Ebling (9) reported the suppression of idiotype bearing anti-DNA antibodies in the sera of young mice given repeated inoculations of a monoclonal cross-reactive antiidiotype before the appearance of the idiotypic IgG in their serum. Inoculations begun after the appearance of idiotype bearing anti-DNA antibodies led to a diminution but not an absence of such antibodies. We have not quantitated the degree of suppression of the 3I idiotype bearing anti-DNA antibodies in our study system. Since an undetermined but presumably variable portion of the anti-DNA antibodies produced by each SLE patient bears the 3I reactive idiotype, it is probable that the $44 \%$ mean suppression seen with the addition of $14 \mu \mathrm{g}$ of $3 \mathrm{I}$ represents a higher percent inhibition of 3I-reactive anti-DNA antibodies. We have previously shown in four patients that from $40 \%$ to over $90 \%$ of the anti-DNA antibody is reactive with the $3 \mathrm{I}$ antiidiotype. The antiidiotype used in our experiments differs from the autologous antiidiotype described by Abdou et al. (8) as it is not binding site specific. It has been proposed that antiidiotypes directed to framework determinants may have a role in regulation.

There are two well-documented reports of the inhibition of synthesis of specific idiotypic rheumatoid factor by PBMC in vitro after incubation with antiidiotype. Koopman et al. (2), using PBMC from a patient with B cell lymphoma that synthesized an IgM kappa rheumatoid factor, were able to suppress the synthesis of the paraprotein by the addition of a rabbit polyclonal antiidiotype. Both IgG and $\mathrm{F}\left(\mathrm{ab}^{\prime}\right)_{2}$ but not $\mathrm{Fab}$ fragments of the IgG antiidiotype were effective, but the concentration of the $\mathrm{F}\left(\mathrm{ab}^{\prime}\right)_{2}$ required to produce $50 \%$ inhibition was five times greater than the concentration of $\mathrm{IgG}$. At $10 \mu \mathrm{g}$ of anti-idiotypic IgG per $2 \times 10^{5} \mathrm{PBMC} / \mathrm{ml}$, the appearance of the idiotype bearing rheumatoid factor in the culture medium after $5 \mathrm{~d}$ of incubation was virtually abolished. Takeuchi et al. (3) also examined the effect of a cross-reactive mouse monoclonal antiidiotype on the synthesis of idiotype bearing $\left(K_{\mathrm{a}}\right)$ rheumatoid factor by human peripheral blood lymphocytes from patients with rheumatoid arthritis in culture. They could suppress rheumatoid factor synthesis $81 \%$ by the addition of $10 \mu \mathrm{g}$ of IgG antiidiotype per $10^{6}$ cells in $200 \mu$ incubated with pokeweed mitogen for $5 \mathrm{~d}$, while $\mathrm{F}\left(\mathrm{ab}^{\prime}\right)_{2}$ fragments of the antiidiotype had no effect on this system. We found significant inhibition by the $\left.\mathrm{F}(\mathrm{ab})_{2}\right)_{2}$ fragment of our antiidiotype.

Our results with anti-DNA antibodies and those described above with rheumatoid factor demonstrate that it is possible to suppress the synthesis of a specific idiotypic human autoantibody in vitro by the addition of antiidiotype. It is not yet clear what regulatory mechanisms are responsible for this suppression, nor the possible physiologic role of a cross-reactive antiframework antiidiotype as opposed to an antiidiotype directed at the combining site. It remains to be determined whether manipulations of the immune response by such antiidiotypes has any utility in the management of diseases of altered immunity.

\section{Acknowledgments}

The authors wish to thank Rita Craig and Anne Lazo for their excellent technical assistance, Lynne Enoch and Rosalia Cawley for their help in the preparation of this manuscript, and Dr. Seymour P. Halbert.

This work was supported by grants from National Institutes of Health (AM-32371) and (AI-10702) and a Clinical Research Center grant from the Arthritis Foundation. Dr. Epstein was supported by a fellowship grant from the New York Chapter of the Arthritis Foundation. Dr. Diamond is an Established Investigator of the American Heart Association and a recipient of an Irma $T$. Hirschl Award.

\section{References}

1. Jerne, N. K. 1974. Towards a network theory of the immune system. Ann. Immunol. 125C:373-389.

2. Abdou, N., H. Wall, H. B. Lindsley, J. F. Halsey, and T. Suzuki. 1981. Network theory in autoimmunity. In vitro suppression of serum anti-DNA binding to DNA by antiidiotypic antibody in systemic lupus erythematosus. J. Clin. Invest. 67:1297-1304.

3. Hahn, B. H., and F. M. Ebling. 1984. Suppression of murine lupus nephritis by administration of an anti-idiotypic antibody to anti-DNA. J. Immunol. 132:187-190.

4. Koopman, W. J., R. E. Schrohenloher, J. C. Barton, and E. C. Greenbaf. 1983. Suppression of an in vitro monoclonal rheumatoid factor synthesis by antiidiotypic antibody. Target cells and molecular requirements. J. Clin. Invest. 72:1410-1419.

5. Takeuchi, T., O. Hosono, J. Koide, M. Homma, and T. Abe. 1985. Suppression of rheumatoid factor synthesis by antiidiotypic antibody in rheumatoid arthritis patients with crossreactive idiotypes. $\mathrm{Ar}$ thritis Rheum. 28:873-881.

6. Solomon, G., J. Schiffenbauer, H. D. Keiser, and B. Diamond. 1983. Use of monoclonal antibodies to identify shared idiotypes on human antibodies to native DNA from patients with systemic lupus erythematosus. Proc. Natl. Acad. Sci. USA. 80:850-854.

7. Tan, E. M., A. S. Cohen, J. F. Fries, A. T. Masi, D. J. McShane, N. F. Rothfield, J. G. Shaller, N. Talal, and R. J. Winchester. 1982. The 1982 revised criteria for the classification of systemic lupus erythematosus. Arthritis Rheum. 25:1271-1277.

8. Halbert, S. R., J. Karsh, and M. Anken. 1981. Studies on autoantibodies to desoxyribonucleic acid and deoxyribonucleoprotein with enzymeimmunoassay (ELISA). J. Lab. Clin. Med. 97:97-111.

9. Takeuchi, T. 1985. Spontaneous production of antibodies to deoxyribonucleic acids in patients with systemic lupus erythematosus. Clin. Immunol. Immunopathol. 35:47-56. 